Available online:

http://journal.imla.or.id/index.php/arabi

Arabi : Journal of Arabic Studies, 6 (1), 2021, 119-134

DOI: http://dx.doi.org/10.24865/ajas.v6i1.341

\title{
PENGEMBANGAN MEDIA PEMBELAJARAN MAHÂRAH AL-KALÂM BERBASIS MEDIA SOSIAL MENGGUNAKAN APLIKASI TIKTOK
}

\author{
Ahmad Zubaidi', Junanah ${ }^{2}$, M. Ja'far Shodiq ${ }^{3}$ \\ ${ }^{12}$ Universitas Islam Indonesia, Yogyakarta, Indonesia \\ ${ }^{3}$ Universitas Islam Negeri Sunan Kalijaga Yogyakarta, Indonesia \\ Corresponding E-mail : ahmad.zubaidi@uii.ac.id
}

\begin{abstract}
This study aims to develop social media-based Mahārah al-kalām learning media using the TikTok application and to test the feasibility of these learning media. In the development of this learning media, the researcher used the ADDIE (analysis, design, development, implementation, and evaluation) development type with 42 students as respondents in the Arabic language course at the Islamic Education Study Program of the Universitas Islam Indonesia with the data collection technique in the form of a questionnaire which included components, material, display, and operation/use. From the feasibility test of learning media by media experts, a percentage of $85.7 \%$ was obtained with the very feasible category, the material expert test obtained a percentage of $92.8 \%$ with a very feasible category. Then the learning media was tested extensively (in the field) to 42 students by getting a percentage of $82.12 \%$ in the very feasible category. The average of the results of the expert tests and trials mentioned above, the percentage results are $86.9 \%$, which means that the social media-based mahärah alkalam (speaking skill) learning media using the TikTok application is very feasible to use.
\end{abstract}

Keywords: learning media, mahārah al-kalām, social media, TikTok application

\begin{abstract}
Abstrak
Penelitian ini bertujuan untuk mengembangkan media pembelajaran mahārah al-kalām berbasis media sosial menggunakan aplikasi TikTok serta menguji kelayakan media pembelajaran tersebut. Dalam pengembangan media pembelajaran ini peneliti menggunakan jenis pengembangan ADDIE (analysis, design, development, implementation, and evaluation) dengan responden sebanyak 42 mahasiswa pada mata kuliah bahasa Arab di Program Studi Pendidikan Agama Islam Universitas Islam Indonesia dengan Teknik pengambilan data berupa angket yang meliputi komponen materi, tampilan, dan pengoperasian/penggunaan. Dari uji kelayakan media pembelajaran oleh ahli media didapatkan persentase sebesar $85,7 \%$ dengan kategori sangat layak, uji ahli materi didapatkan persentase sebesar $92,8 \%$ dengan kategori sangat layak. Kemudian media pembelajaran tersebut diujicobakan secara luas (lapangan) kepada 42 mahasiswa dengan mendapatkan persentase sebesar $82,12 \%$ dalam kategori sangat layak. Rerata dari hasil uji ahli dan uji coba tersebut di atas didapatkan hasil persentase sebesar $86,9 \%$ yang berati bahwa media pembelajaran maharah al-kalam berbasis media sosial menggunakan aplikasi TikTok ini sangat layak untuk digunakan.
\end{abstract}

Kata Kunci: media pembelajaran, mahārah al-kalām, media sosial, aplikasi TikTok 


\section{Arabi : Journal of Arabic Studies}

\section{Pendahuluan}

Pembelajaran daring sangat kurang efektif bagi pendidik maupun peserta didik, terlebih pada masa pandemi Covid-19 yang menuntut pembelajaran dilakukan daring pada saat ini. Penelitian Mustakim menemukan bahwa pesert a didik menilai pembelajaran menggunakan media online sangat efektif (23,3\%), sebagian besar mereka menilai efektif $(46,7 \%)$, dan menilai biasa saja (20\%). Meskipun ada juga peserta didik yang menganggap pembelajaran daring tidak efektif (10\%) (Mustakim, 2020). Apabila dilihat dari efektivitas, pembelajaran daring belum mampu membuat tujuan pembelajaran tercapai. Ketidaksiapan mahasiswa dan dosen baik dari sisi kemampuan menggunakan teknologi maupun ketersediaan sarana pembelajaran yang memadai, koneksi jaringan internet yang buruk di tempat tinggal, biaya, dan belum mampunyai akses, mahasiswa serta dosen beradaptasi dengan metode pembelajaran yang baru untuk dapat meghadirkan kondisi kelas yang kondusif secara virtual menjadi faktor yang membuat pembelajaran daring belum efektif dilaksanakan (Damayanthi, 2020). Dampak yang ditimbulkanpun juga sangat memprihatinkan mahasiswa, seperti (1) pembelajaran daring masih membingungkan mahasiswa (2) mahasiswa menjadi pasif, kurang kreatif dan produktif, (3) penumpukan informasi/konsep pada mahasiswa kurang bermanfaat, (4) mahasiswa mengalami stress, (5) peningkatan kemampuan literasi bahasa mahasiswa.(Argaheni, 2020) Di luar hal tersebut di atas, pendidik ditunt ut unt uk selalu menciptakan pembelajaran daring yang lebih baik daripada pembelajaran luring. Strategi, media, metode, dan materi pembelajaran harus disiapkan oleh pendidik jauh hari sebelum pembelajaran dimulai dan dengan pengembangan yang lebih spesifik, mudah, dan tercapai.

Jika pendidik melakukan persiapan pembelajaran yang maksimal (dalam konteks pembelajaran daring), maka akan dihasilkan hasil pembelajaran yang maksimal. Beberapa penelitian melakukan eksperimen bahwa hasil pembelajaran daring diperoleh angka yang sama dibandingkan pembelajaran luring dengan tanpa mengambil aspek kepuasan peserta didik dalam pembelajaran daring (Navarro \& Shoemaker, 2000). Bahkan hasil pembelajaran daring lebih tinggi angkanya dibandingkan dengan pembelajaran luring.(Rovai \& Jordan, 2004) Pembelajaran daring dapat lebih efektif dalam hal pembiayaan serta produktivitas, dengan hasil yang sama dibandingkan dengan pembelajaran luring (G. Bowen, etc, n.d.), tetapi dengan syarat medianya harus dikembangkan dan diuji secara terus menerus (Harmon \& Lambrinos, 2006). Pembelajaran daring akan lebih efektif jika semua kegiatan pembelajaran terpusat pada peserta didik (Grant \& Courtoreille, 2007) secara berkelompok bukan individual (Suh, 2005). Hal terpenting yang harus dilakukan pendidik adalah menggunakan berbagai strategi untuk meningkatkan pembelajaran daring (Yulia, 2020). Sehingga hal utama yang menjadi sasaran pembelajaran daring adalah terletak pada media pembelajaran yang digunakan.

Permasalahan yang ada pada pembelajaran mahärah al-kaläm (keterampilan berbicara) juga banyak dijumpai dalam pembelajaran yang dilakukan oleh guru, di antaranya adalah lingkungan yang kurang mendukung dalam pembelajaran serta kurangnya minat yang kuat dalam pembelajaran mahärah al-kaläm (Nurlaela, 2020). Permasalahan itu seringkali terjadi pada penyampaian atau cara penyajian dalam pembelajaran mahārah al-kalām terlebih dalam media pembelajaran yang digunakan.

Belum adanya media yang sangat menarik minat dan lingkungan pembelajaran untuk digunakan sebagai pembelajaran mahārah al-kalām. Bahasa Arab menjadi salah satu permasalahan yang harus segera diselesaikan. Dalam melakukan evaluasi keterampilan berbicarapun masih belum maksimal dalam melakukan evaluasi, seperti contoh pada TOEFL IBT yang masih menggunakan Komputer maupun TOAFL. Keterampilan berbicara berhubungan dengan kemampuan lisan, bukan tulisan. Maka untuk memberikan evaluasi pada keterampilan tersebut, tes lisan adalah salah satu hal yang sangat objektif. Begitu juga dalam media pembelajarannya, pembelajaran berbasis interaktif (lisan) akan sangat lebih efektif. Jika dalam konteks luring, hal itu sangat mudah untuk dilakukan secara langsung antara pendidik dan peserta didik tetapi, namun jika dikaitkan dengan pembelajaran daring, masih belum banyak yang dapat memaksimalkan pembelajaran interaktif tersebut. Masih banyak peserta didik yang menyukai pembelajaran berbasis role playing (Muslimin, 2015).

Vol. 6 No. 1 | 120-134

Copyright (C) 2021 | ARABI | p-ISSN 2548-6616 | e-ISSN 2548-6624 
Keterampilan berbicara menjadi salah satu aspek penting dari 4 (empat) aspek keterampilan berbahasa dalam kemampuan berbahasa seseorang khususnya pada Bahasa kedua, yakni Bahasa Arab. Dalam konteks pembelajaran bahasa Arab, mahārah al-kalām termasuk keterampilan pokok yang harus dikuasai siswa dan merupakan salah satu tujuan akhir pembelajaran bahasa Asing (Kuswoyo, 2017). Vallet dalam Fathi Ali Yunus mengatakan bahwa sejak lebih dari 22 tahunan yang lalu, di antara faktor yang mendorong siswa untuk mempelajari bahasa Asing adalah agar bisa berkomunikasi dengan penut ur bahasa yang dipelajarinya, termasuk komunikasi lisan (Subar, 2000, 12). Senada dengan pendapat Vallet, Mahmud Kamil an-Naqah mengatakan bahwa urgensi kemahiran berbicara dalam konteks pembelajaran bahasa Asing tampak pada aspek lisan pada bahasa itu sendiri. Aspek berbicara merupakan aspek utama dalam kurikulum pembelajaran bahasa Asing. Bahkan sebagian besar praktisi pembelajaran bahasa Asing menganggap kemahiran berbicara sebagai tujuan utama dari program pembelajaran bahasa Asing (an-Naqah, 1985, 151). Kalau kita perhatikan dengan seksama, sesungguhnya pendapat Vallet dan an-Naqah tersebut sangat rasional, karena dalam kehidupan sehari-hari ketika kita mengatakan bahwa seseorang mahir dalam bahasa Inggris misalnya, maka yang terbetik di benak kita adalah bahwa orang tersebut cakap berbicara bahasa Inggris.

Dalam mengupayakan kemampuan di atas, model Interactive learning merupakah salah satu metode yang tepat digunakan untuk pembelajaran mahärah al-kaläm yang langsung berhubungan dengan lisan. Interaktif berarti bersifat saling mempengaruhi. Artinya dalam pembelajaran bahasa Arab (keterampilan berbicara) ada hubungan timbal balik antara mahasiswa satu dengan mahasiswa yang lainnya secara aktif dan berpusat kepada mahasiswa itu sendiri. Mahasiswa harus berperan aktif dalam pembelajaran ini. Konsep ini menekankan pada pandangan bahasa, tentang pembelajaran, dan orang-orang yang terlibat atau dalam arti disebut dengan pola interaksi. Orang dewasa dalam hal ini dosen, berkewajiban untuk menyediakan lingkungan yang menunjang mahasiswa (Saputra, 2017).

Teknologi dan media kontemporer sangat memungkinkan pembelajaran dan berbagai macammacam ilmu secara online (Anderson \& Dron, 2014). Dalam konteks pembelajaran daring, media sosial sebagai sarana untuk berinteraksi, berkomunikasi, dan saling berbagi menggunakan bantuan internet, tidak hanya itu, media sosial juga digunakan sebagai alat ekspresi diri (self expression) dan pencitraan diri (self branding) (Kaplan \& Haenlein, 2010). Karenanya interaksi sosial adalah atribut penting untuk mentransfer pengetahuan individu (Polanyi, 2009). Bentuknya dapat berupa jejaring sosial (misalnya Facebook), blog, wiki (misalnya Wikipedia), podcast, forum, media berbasis isi (misalnya Youtube), dan microblog (missal Twitter) (Galuh, 2017, 15). Media sosial sebagai sebuah kelompok aplikasi berbasis internet yang membangun di atas dasar ideologi dan teknologi Web 2.0, dan yang memungkinkan penciptaan dan pertukaran user-generated content (Cahyono, 2016). Sedangkan menurut Humas Kementerian Perdagangan RI, media sosial adalah sebuah media online, dimana para penggunanya (user) melalui aplikasi berbasis internet dapat berbagi, berpartisipasi, dan menciptakan konten berupa blog, wiki, forum, jejaring sosial, dan ruang virtual yang disokong oleh teknologi multimedia yang kian canggih (Nastiti, 2016). Media sosial dapat memfasilitasi penciptaan dan berbagi pengetahuan di antara orang-orang dengan tujuan dan sikap yang sam (Wahlroos \& Katariina, 2011), menghasilkan pandangan alternatif dan ide-ide baru dalam komunitas on line (Eteläpelto \& Lahti, 2008). Orang cenderung bersikap positif terhadap pembelajaran kolaboratif di media sosial karena mereka memberikan pengalaman dan motivasi yang lebih interaktif selama terlibat dalam kegiatan terkait pengetahuan (Manca \& Ranieri, 2016). Salah satu media sosial yang banyak digunakan peserta didik dalam hal ini mahasiswa saat ini adalah media soscial TikTok. Banyak sekali pengguna dari aplikasi tersebut karena bagi penggunanya media sosial ini bisa menghibur penggunanya dikala mereka bosan, apalagi dikala pembelajaran yang serba daring, semua tugas dibebankan kepada mahasiswa yang terbilang tidak sedikit (Hutamy et al., 2021). 


\section{Arabi : Journal of Arabic Studies}

Aplikasi TikTok adalah sebuah jaringan social dan platform video music Tiongkok yang diluncurkan pada September 2016. Aplikasi tersebut membolehkan para pemakai untuk membuat videi music pendek mereka sendiri. Sepanjang kuartal pertama (Q1) 2018 TitTok mengukuhkan diri sebagai aplikasi paling banyak diunduh yakni 45,8 juta kali. Jumlah itu mengalahkan aplikasi populer lain semacam Youtube, WhatApps, Facebook Mesengger, dan Instagram. Ada sekitar 10 juta pengguna aktif aplikasi TikTok di Indonesia. Mayoritas dari pengguna aplikasi TikTok di Indonesia sendiri adalah anak milenial, usia sekolah, atau biasa dikenal dengan generasi Z (Media, n.d.). Salah satu regulasi yang ditengarai adalah batas usia pengguna, yaitu usia 11 tahun. Melihat fakta jumlah pengguna yang mencapai 10 juta lebih di Indonesia dan mayoritas merupakan anak usia sekolah, maka dapat diketahui bahwa aplikasi TikTok menjadi primadona, digandrungi, dan menarik minat para milenial. TikTok dapat diolah menjadi media pembelajaran yang menarik dan interaktif bagi peserta didik. Di dalam hal pengalaman pengguna, TikTok telah mengoptimalkan pengalaman dalam hal desain antarmuka dan model produksi konten interaktif (Yu, 2019). Serta aplikasi tersebut ramah digunakan sekaligus dapat memberikan produksi konten secara lebih luas dan mudah untuk digunakan dalam pembelajaran (Dilon, 2020). Tiktok adalah aplikasi audio-visual yang menyediakan kemampuan pedagogis, pengalaman realistis, peningkatan motivasi, dan pelibatan mahasiswa sebagai pencipta.(Koumi, 2015) Serta sangat bagus untuk menunjang kreativitas mahasiswa (Jung \& Zhou, 2019). Aplikasi TikTok dapat diimplementasikan sebagai media pembelajaran Bahasa Arab. Melihat berbagai fitur yang ada pada aplikasi TikTok, sangat dimungkinkan untuk didesain sebagai media pembelajaran Bahasa Arab yang dalam hal ini berfokus pada keterampilan berbicara yang butuh sebuah pembelajaran interaktif.

Penelitian ini memberikan temuan dan kontribusi kepada para pengajar bahasa Asing khususnya bahasa Arab pada aspek keterampilan berbicara dengan memanfaatkan dan memaksimalkan metode interactive learning dengan memakai aplikasi TikTok, cara dan metode penggunaannya.

\section{Metode Penelitian}

Penelitian ini merupakan jenis penelitian pengembangan yang berorientasi pada pengembangan produk. Produk yang dihasilkan berupa media pembelajaran mahārah al-kalām berbasis media sosial menggunakan aplikasi TikTok. Model pengembangan yang digunakan dalam mengembangkan media pembelajaran ini adalah ADDIE (Analysis, Design, Development, Implementation, and Evaluation). Secara garis besar penelitian ini melakukan tahapan sebagai berikut:

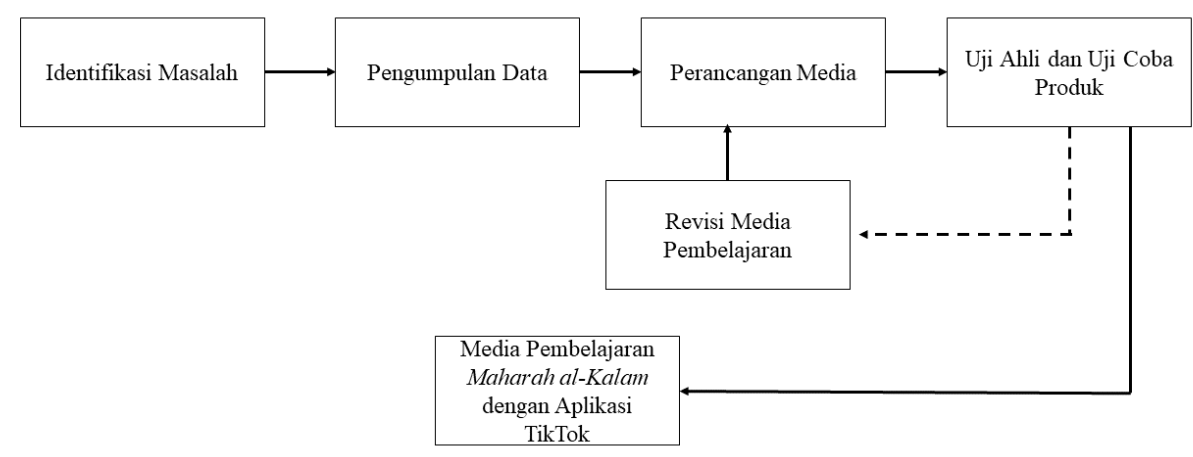

Gambar 1: tahapan penelitian

Pertama, Indentifikasi masalah yang penulis lakukan untuk mengumpulkan motivasi penelitian dari masalah pembelajaran daring pada mata kuliah bahasa Arab di masa pandemi covid19. Berdasarkan informasi yang diberikan dari TIM blueprint Universitas Islam Indonesia menyatakan bahwa motivasi dan semangat mahasiswa dalam melakukan pembelajaran menurun drastis. Dari sini, perlu terobosan baru untuk mengembangkan pembelajaran yang lebih menarik dan asyik (fun)/belajar dan bermain agar motivasi dan semangat mahasiswa dapat kembali naik. Kedua, pengumpulan data yang penulis lakukan setelah mengetahui masalah yang ada bertepatan pada mata 
kuliah bahasa Arab yang fokus pada sub mahärah al-kalām dengan memilih pendekatan interactive learning dengan menggunakan aplikasi on line sosial media yang banyak digunakan oleh mahasiswa dan tidak asing bagi yang menggunakan yakni aplikasi TikTok yang di dalamnya ada fitur duet yang mendukung pada pendekatan interactive learning. Ketiga, penulis merancang materi percakapan yang digunakan berdasarkan indikator mahärah al-kalām dari Mahmud Kamil an-Naqah yang kemudian merekamnya dan mengeditnya untuk di upload di media sosial TikTok yang kemudian mahasiswa nantinya dapat melihatnya serta dapat men-duet secara langsung dengan sebelumnya mereka harus menghafal percakapan terlebih dahulu. Keempat, sebelum media digunakan maka penulis mengujicobakan terlebih dahulu kepada ahli media pembelajaran untuk diberikan masukan dan hal apa yang harus ditambahkan atau dikurangi, kemudian Kelima penulis merevisi media pembelajaran tersebut sesuai masukan dari ahli media yang setelahnya Keenam mengujicobakan produk kepada mahasiswa (uji coba lapangan) dan sedikit revisi dari hasil yang didapatkan yang kemudian produksi masal.

\section{Identify Subsections}

Teknik pengumpulan data dilakukan melalui pengamatan terhadap aspek-aspek yang dibutuhkan terkait dengan pengembangan media ini. Pengumpulan dokumen-dokumen dan menggunakan angket, yang digunakan untuk merancang pengembangan media dan menilai kesesuaian media yang dikembangkan dengan tujuan yang ditetapkan serta menentukan kelayakan media pembelajaran mahărah al-kaläm berbasis media sosial menggunakan aplikasi TikTok. Responden yang dilibatkan dalam pengambilan data adalah ahli media dan ahli materi untuk menentukan kelayakan media serta evaluasi media sebagai acuan revisi sebelum diujikan kepada mahasiswa, dan mahasiswa untuk mengetahui penilaian dari setiap komponen dalam media tersebut. Komponen tersebut mencakup materi, tampilan, dan pengoperasian. Dari komponen tersebut dapat diperoleh nilai, dan kemudian dihitung untuk mendapatkan tingkat kelayakan media pembelajaran.

Teknik sampling yang digunakan dalam penelitian adalah simple random sampling, dengan mengambil semua jumlah dari populasi yang ada, karena jumlah populasi yang ada kurang dari 60 orang yaitu sebanyak 42 mahasiswa, sehingga setiap anggota populasi mendapatkan hak yang sama untuk dilakukan penelitian.

Instrumen penelitian pada penelitian dan pengembangan media pembelajaran mahārah alkalām berbasis media sosial menggunakan aplikasi TikTok ini dibuat menjadi 3 (tiga) kelompok besar yang digunakan untuk mengvaluasi media yang dibuat dan mengetahui kelayakan dari media tersebut. Pertama, Instrumen uji kelayakan ahli materi bahasa Arab (mahärah al-kaläm) yang mencakup aspek pemilihan materi, penguasaan materi, penyampaian materi, dan relevansi materi. Kedua, Instrumen uji kelayakan untuk ahli media yang mencakup aspek kualitas teks/kalimat, kualitas background, kualitas warna, kualitas tombol, kualitas gambar, kualitas suara, kualitas video, kualitas animasi, petunjuk penggunaan, dan interaksi dengan media. Ketiga, uji kelayakan media pembelajaran kepada mahasiswa yang mencakup aspek materi dan aspek media.

Sebelum instrumen digunakan dalam penelitian, instrumen diuji cobakan terlebih dahulu kepada 42 mahasiswa Bahasa Arab kelas D Prodi Pendidikan Agama Islam Universitas Islam Indonesia akan validitas dan reliabilitas instrumen menggunakan SPSS versi 24 dengan perolehan hasil sebagai berikut:

\section{Uji Validitas}

Berdasarkan uji validitas untuk ahli media terlihat bahwa $r_{\text {hitung }}$ berkisar antara $0,381-0,901$ nilai tersebut di atas menyatakan bahwa $r_{\text {hitung }}$ lebih besar dari $r_{\text {tabel }}(0,3)$, maka untuk instrumen ahli media dinyatakan valid. Sedangkan untuk instrumen ahli materi didapatkan nilai $\mathrm{r}_{\text {hitung }}$ berkisar antara 0,655-0,966 dan nilai tersebut menyatakan bahwa lebih besar dari $r_{\text {tabel }}(0,3)$ dan dinyatakan valid. 


\section{Arabi : Journal of Arabic Studies}

\section{Uji Reliabilitas}

Pengujian keandalan (reliabel) variable dalam penelitian ini dilakukan dengan menggunakan rumus alpa Cronbach menggunakan aplikasi SPSS versi 24 karena pertanyaan mempunyai skor antara 1 sampai 4 dengan membaca hasil $r_{i i}$. Selanjutnya hasil yang diperoleh diinterpretasikan dengan tingkatan indeks koefisien korelasi 0,800 - 1,00 (sangat tinggi), 0,600-0,799 (tinggi), 0,400 - 0,599 (cukup), 0,200 - 0,399 (rendah), 0,00-0,199 (sangat rendah). Dari penghitungan didapatkan hasil untuk instrumen ahli media adalah:

\begin{tabular}{|r|r|}
\hline $\begin{array}{c}\text { Cronbach's } \\
\text { Alpha }\end{array}$ & N of Items \\
\hline, 985 & 38 \\
\hline
\end{tabular}

Table 1: Reabilitas Ahli Media

Dari tabel di atas dapat dilihat bahwa tingkat koefisien korelasi instrumen untuk ahli materi adalah sangat tinggi karena bernilai 0,985 yaitu berada antara $0,800-0,1000$. Dan untuk ahli materi sebagai berikut.

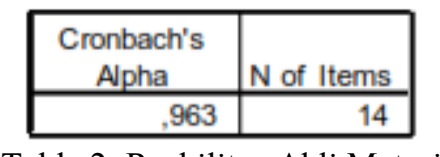

Table 2: Reabilitas Ahli Materi

Dari tabel di atas dapat dilihat bahwa tingkat koefisien korelasi instrumen untuk ahli materi adalah sangat tinggi karena bernilai 0,985 yaitu berada antara $0,800-0,1000$.

Partisipan penelitian dalam pengembangan media ini adalah mahasiswa Program Studi Pendidikan Agama Islam Universitas Islam Indonesia Yogyakarta pada mata kuliah bahasa Arab semester 1 yang di ampu oleh peneliti sendiri yang berada di kelas C sebanyak 42 mahasiswa. Peneliti melakukan beberapa tahap, identifikasi masalah, digunakan peneliti untuk mengidentifikasi masalah yang terjadi pada pembelajaran mahärah al-kaläm yang tidak banyak mendapatkan sorotan dengan media pembelajaran interactive, sedangkan dalam masa pembelajaran daring aplikasi TikTok adalah media sosial yang dapat digunakan pembelajaran oleh mahasiswa dalam mahärah alkalām. Pengumpulan data, peneliti kemudian mengumpulkan data-data mengenai indikator materi mahärah al-kaläm yang berlandaskan pada indikator oleh Mahmud Kamil an-Naqah, kemudian materi tersebut dipilah sesuai Capaian Pembelajaran Mata Kuliah (CPMK) yakni, mahasiswa mampu melakukan percakapan dengan topik perkenalan, mahasiswa mampu melakukan percakapan dalam topik di sekolah, mahasiswa mampu melakukan percakapan dalam topik di rumah, dan mahasiswa mampu melakukan percakapan dalam topik sosial. Perancangan media, dilanjutkan peneliti merancang media dengan membuat rekaman tanya sebagai orang $\mathrm{X}$ dan orang $\mathrm{Y}$ dari semua percakapan yang sudah dipilih berdasarkan topik yang kemudian diunggah ke media sosial TikTok untuk diduet oleh mahasiswa. Uji ahli dan uji coba produk, setelah materi selesai semua didesain peneliti melakukan uji ahli materi oleh M. Jafar Shodiq dari UIN Sunan Kalijaga Yogyakarta, dan uji ahli media serta diujicobakan kepada 42 mahasiswa Program Studi Pendidikan Agama Islam Universitas Islam Indonesia Yogyakarta untuk kelayakan media pembelajaran ini.

Dalam menganalisis data hasil uji coba penulis menggunakan Teknik analisis deskriptif kualitatif yakni dengan menganalisis data kuantitatif yang diperoleh dari angket uji ahli dan lapangan. Data kuantitatif yang berwujud angka-angka hasil penghitungan atau pengukuruan diproses dengan cara dijumlahkan, dibandingkan dengan jumlah yang diharapkan dan diperoleh persentase dengan menggunakan rumus:

$$
\text { Prosentase Kelayakan }(\%)=\frac{\text { Skor yang diobservasi }}{\text { Skor yang diharapakan }} \times 100 \%
$$

Kemudian hasil dari persentasi yang telah dihitung dibuat kriteria pada table berikut: 
Table 3: Kategori kelayakan

\begin{tabular}{lll}
\hline No. & Skor dalam persentase & \multicolumn{1}{c}{ Kategori } \\
\hline 1 & $81 \%-100 \%$ & Sangat Layak \\
\hline 2 & $61 \%-80 \%$ & Layak \\
\hline 3 & $41 \%-60 \%$ & Cukup Layak \\
\hline 4 & $21 \%-40 \%$ & Kurang Layak \\
\hline 5 & $<21 \%$ & Tidak Layak \\
\hline
\end{tabular}

\section{Hasil Penelitian dan Diskusi Hasil}

Dari aspek indikator yang telah penulis jabarkan di atas, diuraikan untuk membuat butir-butir instrumen dalam memperoleh data penelitian ini berupa angket kepada ahli materi dengan 2 aspek kualitas tampilan dan kualitas pengoperasian, dan ahli materi dengan 2 aspek kualitas pembelajaran dan kualitas materi. Uji ini dilakukan dengan menggunakan skala Likert dengan skor 4 (sangat layak), 3 (layak), 2 (cukup layak), 1 (kurang layak). Dari hasil angket yang diberikan kepada ahli media didapatkan hasil sebagai berikut:

Table 4: Hasil Uji Ahli Media

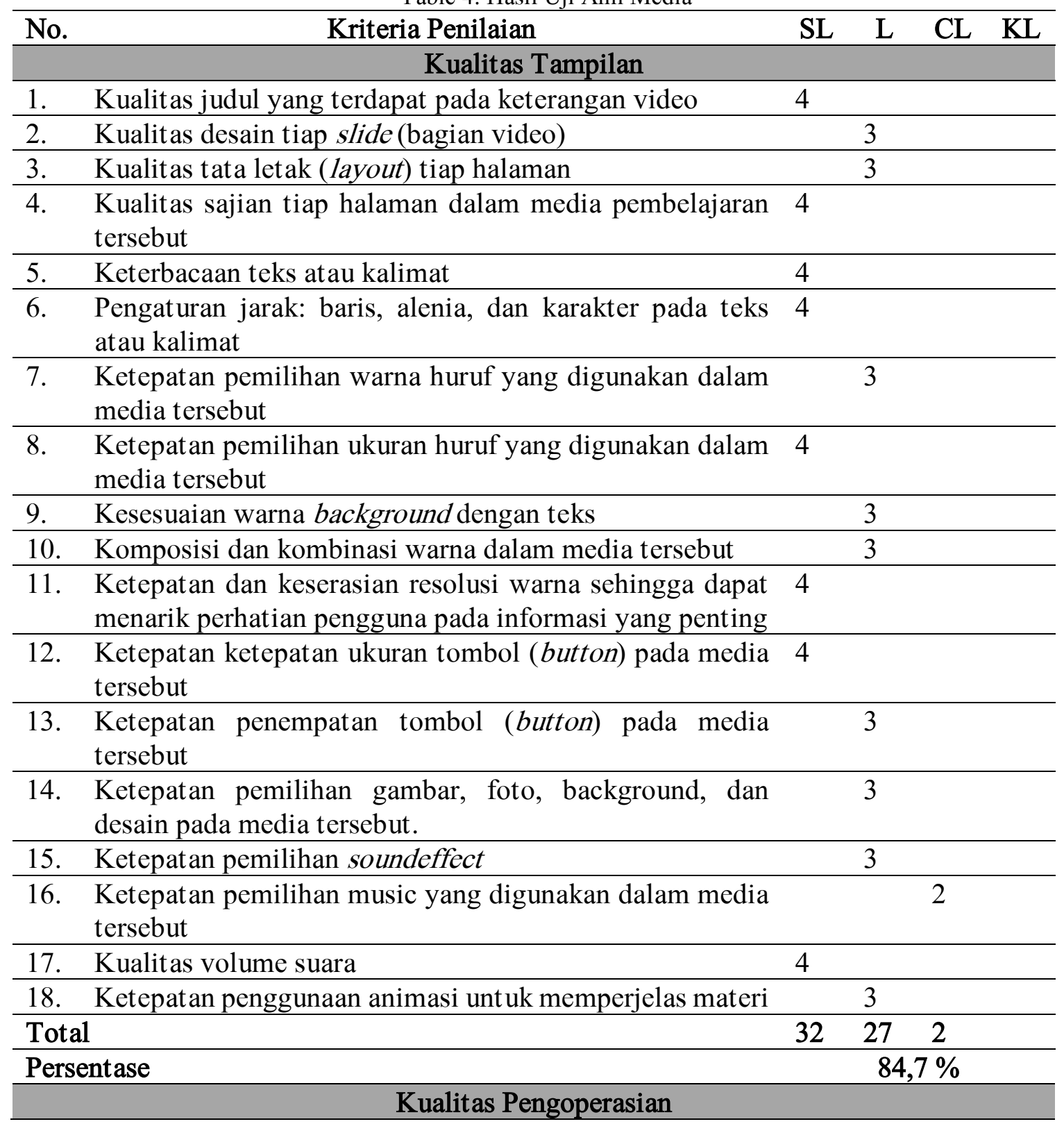




\begin{tabular}{llll}
\hline 19. & $\begin{array}{l}\text { Kejelasan petunjuk penggunaan media pembelajaran } \\
\text { tersebut }\end{array}$ & 4 \\
\hline 20. & $\begin{array}{l}\text { Kualitas media pembelajaran dalam berinteraksi dan } \\
\text { berkomunikasi dengan pengguna }\end{array}$ & 4 & \\
\hline 21. & Kemudahan berinteraksi dengan media tersebut & 4 & \\
\hline $22 . \quad$ Kemudahan memilih menu sajian & 4 & \\
\hline $23 . \quad$ Kemudahan navigasi dalam media tersebut & \multicolumn{2}{l}{3} \\
\hline $24 . \quad$ Kemudahan penggunaan tombol dalam media tersebut & 4 & \\
\hline Total & 20 & 3 \\
\hline Persentase & \multicolumn{2}{c}{$\mathbf{9 5 , 8 \%}$} \\
\hline Persentase Total & $\mathbf{8 7 , 5 \%}$ \\
\hline
\end{tabular}

Kemudian hasil dari ahli materi didapatkan hasil sebagai berikut:

Table 5: Hasil uji ahli materi

\begin{tabular}{|c|c|c|c|}
\hline No. & Kriteria Penilaian & $\mathrm{SL}$ & CL $\quad \mathrm{KL}$ \\
\hline \multicolumn{4}{|c|}{ Kualitas Pembelajaran } \\
\hline 1. & Kejelasan struktur CPMK yang akan dicapai & 4 & \\
\hline 2. & Kejelasan indikator yang harus dicapai oleh mahasiswa & & 3 \\
\hline 3. & Kemampuan penyampaian materi & 4 & \\
\hline 4. & Penyampaian materi menarik mahasiswa & 4 & \\
\hline 5. & $\begin{array}{l}\text { Penyampaian materi sekaligus dapat memberi motivasi } \\
\text { belajar mahasiswa }\end{array}$ & & 3 \\
\hline 6. & Kejelasan simulasi dalam media pembelajaran tersebut & & 3 \\
\hline Tot & & 12 & 9 \\
\hline Pers & ntase & & $87,5 \%$ \\
\hline \multicolumn{4}{|c|}{ Kualitas Materi } \\
\hline 7. & $\begin{array}{l}\text { Ketepatan pemilihan materi yang disampaikan dalam } \\
\text { media tersebut }\end{array}$ & 4 & \\
\hline 8. & Pentingnya materi yang disampaikan & 4 & \\
\hline 9. & Kemanfaatan materi yang disampaikan & 4 & \\
\hline 10. & Daya Tarik materi yang disampaikan & & 3 \\
\hline 11. & Kebenaran konsep materi & 4 & \\
\hline & Kelengkapan, keluasan, dan kedalaman materi & 4 & \\
\hline & Kesesuaian materi dengan kurikulum pembelajaran & 4 & \\
\hline & Kesesuaian materi dengan sutuasi mahasiswa & 4 & \\
\hline \multicolumn{2}{|c|}{ Total } & 28 & 3 \\
\hline \multicolumn{2}{|c|}{ Persentase } & & $96,9 \%$ \\
\hline \multicolumn{2}{|c|}{ Persentase Total } & & $92,8 \%$ \\
\hline
\end{tabular}

Selanjutnya dilakukan uji coba produk yang diimplementasikan kepada 42 mahasiswa Program Studi Pendidikan Agama Islam Mata Kuliah Bahasa Arab (mahārah al-kalām) kelas C Universitas Islam Indonesia yang terdiri dari 3 komponen yakni materi, tampilan, dan pengoperasian yang di dalamnya terdapat beberapa aspek dan indikator. Data ini dikaji untuk mengetahui tanggapan mahasiswa mengenai kelayakan terhadap media pembelajaran yang dihasilkan. Data analisis media selengkapnya dapat dijelaskan dengan mengacu pada Sangat Layak (81\% - 100\%), Layak (61\% - 80\%), Cukup Layak (41\% - 60\%), Kurang Layak (21\% - 40\%), dan Tidak Layak (21\%) didapatkan hasil sebagai berikut: 
Arabi : Journal of Arabic Studies

Table 6: Hasil uji coba produk

\begin{tabular}{|c|c|c|c|c|c|}
\hline No & Komponen & Aspek & Indikator & Hasil & Keterangan \\
\hline \multirow{6}{*}{1.} & \multirow{6}{*}{ Materi } & CPMK & $\begin{array}{l}\text { Kejelasan struktur CPMK yang } \\
\text { akan dicapai }\end{array}$ & $80,15 \%$ & $\begin{array}{l}\text { Sangat } \\
\text { layak }\end{array}$ \\
\hline & & Indikator & $\begin{array}{l}\text { Kejelasan indikator yang harus } \\
\text { dicapai oleh mahasiswa }\end{array}$ & $83,7 \%$ & $\begin{array}{l}\text { Sangat } \\
\text { layak }\end{array}$ \\
\hline & & \multirow{4}{*}{$\begin{array}{l}\text { Penyampaian } \\
\text { materi }\end{array}$} & Kemampuan penyampaian materi & $79,82 \%$ & Layak \\
\hline & & & $\begin{array}{l}\text { Penyampaian materi menarik } \\
\text { mahasiswa }\end{array}$ & $85 \%$ & $\begin{array}{l}\text { Sangat } \\
\text { layak }\end{array}$ \\
\hline & & & $\begin{array}{l}\text { Penyampaian materi sekaligus } \\
\text { dapat memberi motivasi belajar } \\
\text { mahasiswa }\end{array}$ & $87,74 \%$ & $\begin{array}{l}\text { Sangat } \\
\text { layak }\end{array}$ \\
\hline & & & $\begin{array}{l}\text { Kejelasan simulasi dalam media } \\
\text { pembelajaran tersebut }\end{array}$ & $77,9 \%$ & Layak \\
\hline \multicolumn{4}{|c|}{ Persentase Total Komponen Materi } & $82,4 \%$ & $\begin{array}{c}\text { Sangat } \\
\text { layak }\end{array}$ \\
\hline \multirow{14}{*}{2.} & \multirow{14}{*}{ Tampilan } & \multirow{4}{*}{$\begin{array}{l}\text { Kualitas } \\
\text { intro }\end{array}$} & $\begin{array}{l}\text { Kualitas judul yang terdapat pada } \\
\text { keterangan video }\end{array}$ & $91,8 \%$ & $\begin{array}{c}\text { Sangat } \\
\text { layak }\end{array}$ \\
\hline & & & $\begin{array}{l}\text { Kualitas desain tiap slide (bagian } \\
\text { video) }\end{array}$ & $65,7 \%$ & Layak \\
\hline & & & $\begin{array}{l}\text { Kualitas tata letak (layout) tiap } \\
\text { halaman }\end{array}$ & $78,8 \%$ & Layak \\
\hline & & & $\begin{array}{l}\text { Kualitas sajian tiap halaman dalam } \\
\text { media pembelajaran tersebut }\end{array}$ & $76 \%$ & Layak \\
\hline & & \multirow{4}{*}{$\begin{array}{l}\text { Kualitas } \\
\text { teks/kalimat }\end{array}$} & Keterbacaan teks atau kalimat & $93 \%$ & $\begin{array}{l}\text { Sangat } \\
\text { layak }\end{array}$ \\
\hline & & & $\begin{array}{l}\text { Pengat uran jarak: baris, alenia, dan } \\
\text { karakter pada teks atau kalimat }\end{array}$ & $92 \%$ & $\begin{array}{l}\text { Sangat } \\
\text { layak }\end{array}$ \\
\hline & & & $\begin{array}{l}\text { Ketepatan pemilihan warna huruf } \\
\text { yang digunakan dalam media } \\
\text { tersebut }\end{array}$ & $81,7 \%$ & $\begin{array}{l}\text { Sangat } \\
\text { layak }\end{array}$ \\
\hline & & & $\begin{array}{l}\text { Keteapatan pemilihan ukuran } \\
\text { huruf yang digunakan dalam media } \\
\text { tersebut }\end{array}$ & $83,45 \%$ & $\begin{array}{l}\text { Sangat } \\
\text { layak }\end{array}$ \\
\hline & & $\begin{array}{c}\text { Kualitas } \\
\text { background }\end{array}$ & $\begin{array}{l}\text { Keseuaian warna background } \\
\text { dengan teks }\end{array}$ & $80,32 \%$ & $\begin{array}{l}\text { Sangat } \\
\text { layak }\end{array}$ \\
\hline & & \multirow[b]{2}{*}{$\begin{array}{l}\text { Kualitas } \\
\text { warna }\end{array}$} & $\begin{array}{l}\text { Komposisi dan kombinasi warna } \\
\text { dalam media tersebut }\end{array}$ & $82,2 \%$ & $\begin{array}{l}\text { Sangat } \\
\text { layak }\end{array}$ \\
\hline & & & $\begin{array}{l}\text { Ketepatan dan keserasian resolusi } \\
\text { warna sehingga dapat menarik } \\
\text { perhatian pengguna pada } \\
\text { informasi yang penting }\end{array}$ & $81,9 \%$ & $\begin{array}{l}\text { Sangat } \\
\text { layak }\end{array}$ \\
\hline & & \multirow{2}{*}{$\begin{array}{l}\text { Kualitas } \\
\text { desain }\end{array}$} & $\begin{array}{l}\text { Ketepatan ukuran tombol (button) } \\
\text { pada media tersebut }\end{array}$ & $87,12 \%$ & $\begin{array}{l}\text { Sangat } \\
\text { layak }\end{array}$ \\
\hline & & & $\begin{array}{l}\text { Ketepatan penempatan tombol } \\
\text { (button) pada media tersebut }\end{array}$ & $85,64 \%$ & $\begin{array}{c}\text { Sangat } \\
\text { layak }\end{array}$ \\
\hline & & $\begin{array}{l}\text { Kualitas } \\
\text { gambar }\end{array}$ & $\begin{array}{l}\text { Ketepatan pemilihan gambar, foto, } \\
\text { background, dan desain pada } \\
\text { media tersebut. }\end{array}$ & $79,3 \%$ & Layak \\
\hline
\end{tabular}




\begin{tabular}{|c|c|c|c|c|c|}
\hline & & \multirow{3}{*}{$\begin{array}{l}\text { Kualitas } \\
\text { sound }\end{array}$} & Ketepatan pemilihan sound effect & $61,45 \%$ & Layak \\
\hline & & & $\begin{array}{l}\text { Ketepatan pemilihan musik yang } \\
\text { digunakan dalam media tersebut }\end{array}$ & $73,2 \%$ & Layak \\
\hline & & & Kualitas volume suara & $98,9 \%$ & $\begin{array}{c}\text { Sangat } \\
\text { layak }\end{array}$ \\
\hline & & $\begin{array}{l}\text { Kualitas } \\
\text { animasi }\end{array}$ & $\begin{array}{l}\text { Ketepatan penggunaan animasi } \\
\text { untuk memperjelas materi }\end{array}$ & $80,2 \%$ & $\begin{array}{c}\text { Sangat } \\
\text { layak }\end{array}$ \\
\hline & Pers & entase Total K & mponen Tampilan & $81,82 \%$ & $\begin{array}{l}\text { Sangat } \\
\text { layak }\end{array}$ \\
\hline \multirow{6}{*}{3.} & \multirow{6}{*}{ Pengoperasian } & $\begin{array}{c}\text { Petunjuk } \\
\text { penggunaan }\end{array}$ & $\begin{array}{l}\text { Kejelasan petunjuk penggunaan } \\
\text { media pembelajaran tersebut }\end{array}$ & $88,82 \%$ & $\begin{array}{c}\text { Sangat } \\
\text { layak }\end{array}$ \\
\hline & & \multirow{2}{*}{$\begin{array}{l}\text { Interaksi } \\
\text { media dan } \\
\text { pengguna }\end{array}$} & $\begin{array}{l}\text { Kualitas media pembelajaran } \\
\text { dalam berinteraksi dan } \\
\text { berkomunikasi dengan pengguna }\end{array}$ & $93,3 \%$ & $\begin{array}{c}\text { Sangat } \\
\text { layak }\end{array}$ \\
\hline & & & $\begin{array}{l}\text { Kemudahan berinteraksi dengan } \\
\text { media tersebut }\end{array}$ & $77,4 \%$ & Layak \\
\hline & & \multirow{3}{*}{$\begin{array}{c}\text { Kualitas } \\
\text { penggunaan }\end{array}$} & Kemudahan memilih menu sajian & $71,3 \%$ & Layak \\
\hline & & & $\begin{array}{l}\text { Kemudahan navigasi dalam media } \\
\text { tersebut }\end{array}$ & $72,1 \%$ & Layak \\
\hline & & & $\begin{array}{l}\text { Kemudahan penggunaan tombol } \\
\text { dalam media tersebut }\end{array}$ & $89,93 \%$ & $\begin{array}{c}\text { Sangat } \\
\text { layak }\end{array}$ \\
\hline \multicolumn{4}{|c|}{ Persentase Total Komponen Pengoperasian } & $82,14 \%$ & $\begin{array}{l}\text { Sangat } \\
\text { layak }\end{array}$ \\
\hline
\end{tabular}

\section{Diskusi}

Dari hasil data yang didapatkan di atas, penulis memberikan pembahasan secara terperinci dalam penelitian ini berdasarkan tahapan-tahapan yang sudah peneliti jelaskan dalam metode penelitian melalui pendekatan ADDIE sebagai berikut.

\section{Analysis}

Dalam pembelajaran bahasa Arab, mahārah al-kalām adalah mahārah yang penting untuk diterapkan kepada mahasiswa. Dalam konsep yang penulis temukan, interactive learning adalah pendekatan yang paling tepat untuk menerapkan pada pembelajaran mahärah al-kaläm. Problematika yang didapatkan masih belum banyak beberapa dosen yang dapat menerapkan pendekatan tersebut dalam pembelajaran daring saat ini. Media sosial menggunakan aplikasi TikTok adalah analisis penulis secara tepat untuk menerapkan pembelajaran tersebut. Dari sisi lain peneliti dalam hal ini juga mempersiapkan materi-materi yang dipilih sesuai dengan indikator pencapaian mahärah al-kaläm dalam Mahmud Kamil an-Naqah sebanyak 4 capaian pembelajaran mata kuliah.

Dalam capaian tersebut, peneliti membagi ke dalam 4 aspek pembelajaran inti, pertama adalah kemampuan mahasiswa dalam bercakap-cakap dalam ranah perkenalan dengan benar dari segi lahjah/pronunciation sesuai kaidah bahasa Arab dengan baik dan benar, kedua adalah kemampuan mahasiswa dalam bercakap-cakap dalam ranah/tema di sekolah dengan benar dari segi lahjah/pronunciation sesuai kaidah bahasa Arab dengan baik dan benar, ketiga adalah kemampuan mahasiswa dalam bercakap-cakap dalam ranah/tema di rumah dengan benar dari segi lahjah/pronunciation sesuai kaidah bahasa Arab dengan baik dan benar, keempat adalah kemampuan mahasiswa dalam bercakap-cakap dalam ranah sosial dengan benar dari segi lahjah/pronunciation sesuai kaidah bahasa Arab dengan baik dan benar. Dari capaian tersebut peneliti membagi ke dalam percakapan-percakapan sesuai dengan capaian yang ada, dari tiap-tiap capaian ada 4 percakapan dan 4 kosakata jadi sehari-hari yang nantinya harus dihafalkan oleh tiap-tiap mahasiswa. 


\section{Design}

Setelah peneliti menganalisis dari segi pelaksanaan pembelajaran yang dilakukan, peneliti mendesain pembelajaran dengan memakai percakapan orang $\mathrm{X}$ dan $\mathrm{Y}$. Dosen mempersiapkan rekaman percakapan dan sebelum itu dosen membuat percakapan sebanyak 16 percakapan dan 16 kosakata sehari-hari yang berhubungan dengan capaian pembelajaran mata kuliah. Kemudian dosen melakukan rekaman percakapan sebagai orang X dan orang Y yang selanjutnya unggah pada aplikasi TikTok seperti gambar berikut:

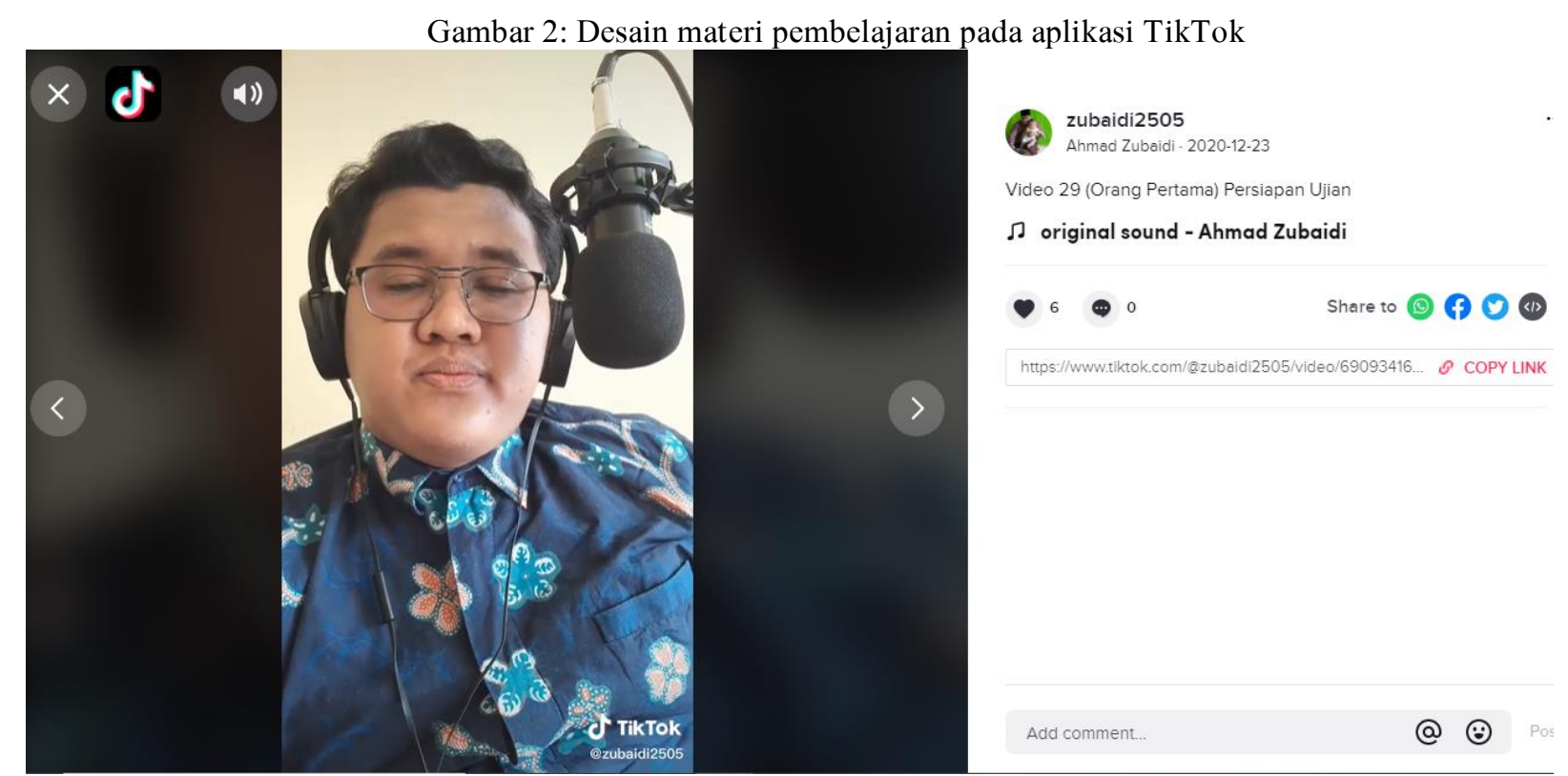

Setelah dosen mengupload semua materi yang ada, kemudian pengguna (mahasiswa) menghafalkan percakapan sesuai denga napa yang sudah ada dalam bahan ajar yang diunggah oleh dosen melalui fitur bit.ly/ untuk mengunduh materi tersebut. Setelah mahasiswa menghafalkan percakapan mahasiswa mencari materi dalam media pembelajaran sesuai dengan tema yang sudah dihafalkan dan selanjutnya memilih fitur duet yang ada dalam aplikasi TikTok untuk melakukan percakapan bersama dengan video yang sudah diunggah oleh dosen sebagaimana terlihat pada gambar berikut:

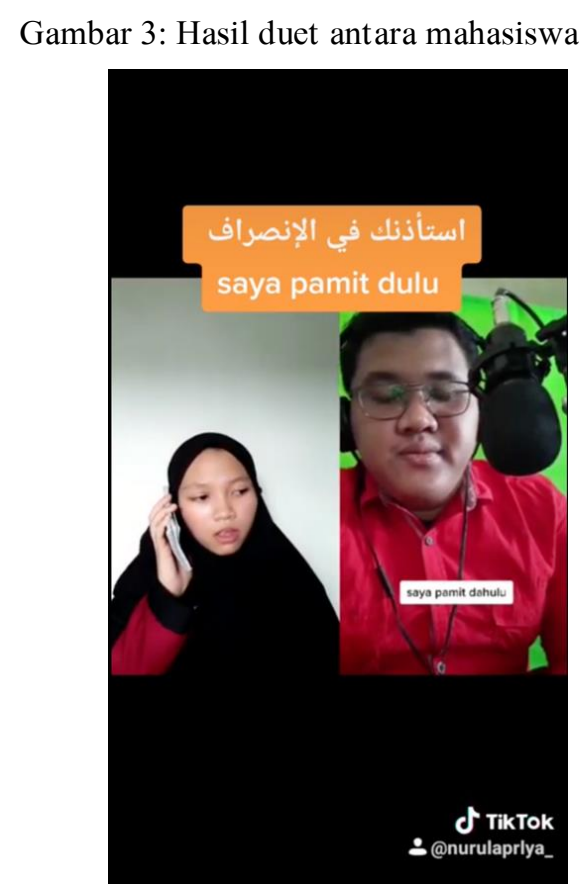




\section{Arabi : Journal of Arabic Studies}

\section{Development}

Kemudian peneliti memasukkan video tersebut ke dalam aplikasi TikTok yang harus dijawab oleh mahasiswa dengan memberikan kemaksimalan suara dalam kejelasan pendengaran pengguna, sehingga pengguna dapat mendengarkan dengan jelas lahjah/pronunciation secara lebih peka. Dalam hal ini pengembangan yang dibuat oleh peneliti diujikan kepada ahli media dan ahli materi.

Penilaian oleh ahli media meliputi komponen tampilan dan pengoperasian/penggunaan media pembelajaran mahärah al-kaläm berbasis media sosial menggunakan aplikasi TikTok yang menunjukkan bahwa komponen tampilan media pembelajaran mendapatkan persentase sebesar $84,7 \%$. Hal ini menunjukkan bahwa tampilan media pembelajaran mahärah al-kalām berbasis media sosial menggunakan aplikasi TikTok termasuk dalam kategori sangat layak. Hal tersebut berdasarkan penelitian Utami (2021) menyatakan bahwa aplikasi tiktok adalah media hiburan masyarakat yang paling menarik dari media sosial edit video social effect (Utami, 2021). Sedangkan komponen pengoperasian/penggunaan media pembelajaran didapatakan hasil persentase sebesar 95,8\% dan hal itu menunjukkan bahwa pengeoperasian/penggunaan media pembelajaran mahärah al-kalām berbasis media sosial menggunakan aplikasi TikTok berada dalam kategori sangat layak. Bahkan penggunanya yang berkonten pendidikan di antaranya bahasa dan matematika mencapai 9,3 miliar dengan samasamabelajar kerjasama dengan Kemendikbud (Mabruroh et al., 2020). Pada uji ahli media ini didapatkan dengan rerata persentase sebesar $85,7 \%$ yang berarti bahwa media pembelajaran mahärah al-kalām berbasis media sosial menggunakan aplikasi TikTok ini sangat layak untuk digunakan yang kemudian berlanjut pada tahap penelitian yakni uji coba lapangan kepada 42 mahasiswa Pendidikan Agama Islam di mata kuliah Bahasa Arab.

Penilaian oleh ahli materi meliputi komponen kualitas pembelajaran dan kualitas materi media pembelajaran mahārah al-kalām berbasis media sosial menggunakan aplikasi TikTok. Hasil dari pengujian ahli materi menunjukkan bahwa komponen kualitas pembelajaran media pembelajaran ini diperoleh persentase sebesar 87,5\%. Hal tersebut menunjukkan bahwa kualitas pembelajaran media pembelajaran mahärah al-kalām berbasis media sosial menggunakan aplikasi TikTok termasuk dalam kategori sangat layak, sedangkan dari komponen kualitas materi pembelajaran dari ahli materi diperoleh persentase sebesar $96,6 \%$ yang juga masuk dalam kategori sangat layak. Materi yang dibuat dalam aplikasi TikTok mudah diakses dan lebih mudah untuk diserap oleh mahasiswa, sebanyak $82,7 \%$ mahasiswa setuju dengan hal tersebut (Hayes et al., 2020). Rerata yang diperoleh dari uji ahli materi yang meliputi komponen kualitas pembelajaran dan kualitas materi media pembelajaran ini adalah $92,8 \%$ yang mana hal tersebut menunjukkan bahwa materi yang digunakan dalam pengembangan media pembelajaran mahärah al-kalām berbasis media sosial menggunakan aplikasi TikTok ini berada dalam kategori sangat layak digunakan yang selanjutnya digunakan oleh peneliti untuk uji lapangan kepada mahasiswa.

\section{Implementation}

Setelah mendapatkan hasil dari uji ahli, peneliti mengujicobakan media pembelajaran mahārah al-kalām berbasis media sosial menggunakan aplikasi TikTok secara lebih luas (uji lapangan) dengan responden sebanyak 42 mahasiswa Program Studi Pendidikan Agama Islam Universitas Islam Indonesia dengan jangka waktu selama 1 semester di mata kuliah Bahasa Arab. Dari uji coba lapangan tersebut peneliti memberikan angket kepada mahasiswa yang telah disusun sesuai dengan indikator yang telah penulis jelaskan pada bab sebelumnya, dan didapatkan hasil dari data yang telah ada sebagai berikut.

Hasil penilaian yang dilakukan oleh 42 mahasiswa semester 1 Program Studi Pendidikan Agama Islam Universitas Islam Indonesia pada mata kuliah Bahasa Arab meliputi 3 komponen yakni

komponen kualitas materi pembelajaran, tampilan media pembelajaran, dan pengoperasian/penggunaan media pembelajaran. Hasil uji coba lapangan menunjukkan bahwa komponen kualitas materi pembelajaran diperoleh persentase sebesar $82.4 \%$ dan hal tersebut menunjukkan bahwa hasil uji coba lapangan mengatakan sangat layak dari aspek/komponen

Vol. 6 No. 1 | 130-134

Copyright (C) 2021 | ARABI | p-ISSN 2548-6616 | e-ISSN 2548-6624 
materinya. Dari aspek materi, aplikasi TikTok menurut peserta didik adalah media yang paling mudah digunakan dalam akses materinya dan tidak membutuhkan kuota banyak (Patricia AguileraHermida, 2020). Kemudian dari komponen kualitas tampilan media pembelajaran dari hasil di atas diperoleh persentase sebesar $81,82 \%$ dan hasil tersebut mengatakan bahwa komponen tampilan media pembelajaran ini juga sangat layak digunakan. Aspek tampilan media pembelajaran TikTok dalam hal ini dapat meningkatkan motivasi peserta didik dalam melakukan pembelajaran (Nabilah et al., 2021). Selanjutnya dari komponen pengoperasian/penggunaan media pembelajaran yang dari hasil uji coba lapangan kepada mahasiswa tersebut didapatkan persentase sebesar $82.14 \%$ yang ini sesuai dengan penelitian Ioana (2021) bahwa pengoperasin aplikasi TikTok sangat mudah (Literat, 2021). dan hasil tersebut menunjukkan bahwa pengoperasian/penggunaan media pembelajaran mahārah al-kalām ini sangat layak untuk digunakan. Karena itu, penulis membuat rerata dari hasil uji coba lapangan kepada mahasiswa yang meliputi komponen materi, tampilan, dan pengoperasian/penggunaan adalah $82,12 \%$ yang berati bahwa media pembelajaran mahărah al-kaläm berbasis media sosial menggunakan aplikasi TikTok tersebut sangat layak untuk digunakan dalam pembelajaran Bahasa Arab. Semangat mahasiswa dalam melakukan pembelajaran melalui media TikTok juga bertambah dengan minat mereka untuk mengulanginya berkali-kali (Pratiwi et al., 2021)

\section{Evaluation}

Dari proses uji ahli materi, uji ahli media, dan uji coba lapangan kepada mahasiswa ada beberapa poin yang harus dievaluasi dari 3 komponen yakni komponen materi kualitas materi pembelajaran, tampilan media pembelajaran, dan pengoperasian/penggunaan media pembelajaran yang sudah ada dalam instrumen yang digunakan dalam penelitian ini.

Komponen kualitas materi pembelajaran ditemukan pada tabel hasil di atas bahwa indikator pencapaian materi pembelajaran masih kurang, sehingga perlu adanya sebuah indikator secara lebih valid dan menyeluruh dari pembelajaran mahärah al-kalām. Indikator yang disampaikan kurang spesifik dalam mengevaluasi hasil dari pembelajaran sehingga, kespesifikan dari indikator tersebut perlu untuk ditinjau ulang kembali. Kemudian materi juga belum menarik mahasiswa untuk lebih meningkatkan motivasinya dalam belajar bahasa Arab yang itu harus ada pemilihan secara lebih kooperatif akan materi yang sudah dijadikan sebagai bahan ajar dalam pembelajaran serta kejelasan simulasi materi mana saja yang harus disampaikan juga harus ada dalam media pembelajaran tersebut.

Komponen tampilan media pembelajaran juga ditemukan nilai yang sangat minim dalam hal ketepatan pemilihan musik yang ada dalam media pembelajaran. Dalam media tersebut tidak ada musik pengiring sama sekali, sehingga mahasiswa merasa bosan dalam melakukan duet percakapan dengan dosen, sebagai bahan evaluasi, media tersebut ditambahkan music sebagai latar belakang guna citra TikTok yang terkesan 'fun' tidak hilang. Kemudian background /atar belakang yang peneliti gunakan hanya sebatas warna hijau, dan itu menghilangkan citra mahasiswa untuk bisa menerapkan dalam kehidupan yang nyata, sehingga evaluasi dari hal tersebut peneliti menambahkan latar belakang percakapan yang sesuai dengan apa yang sedang dibicarakan oleh mutakallim mukhathab dalam melakukan percakapan. Kemudian juga pemilihan animasi yang ada juga belum muncul dalam penelitian ini. Seharusnya apa ketika melakukan percakapan, ada animasi yang mengantarkan untuk lebih jelas dalam memahami isi dari percakapan tersebut, walaupun mahasiswa lupa akan materi yang dihafalkan, dengan bantuan animasi yang ada dalam media pembelajaran tersebut lebih meningkatkan ingatan mahasiswa dalam melakukan percakapan.

Komponen pengoperasian/penggunaan masih kurang dalam navigasi yang ada dalam media pembelajaran ini, sehingga lebih membuat pengguna bingung hal apa yang seharusnya dilakukan dalam mengikuti pembelajaran bahasa Arab menggunakan aplikasi TikTok tersebut yang seakanakan diharuskan bagi peneliti untuk bertemu secara langsung terlebih dahulu dengan pengguna yang harus memberikan penjelasan mengenai pembelajaran yang ada dalam aplikasi tersebut yang 


\section{Arabi : Journal of Arabic Studies}

kemudian peneliti memberikan alternatif sebuah link yang bisa diakses oleh pengguna dalam melakukan pembelajaran mahārah al-kalām menggunakan media pembelajaran aplikasi TikTokini.

\section{Simpulan}

Penelitian ini adalah penelitian pengembangan yang fokus pada media pembelajaran mahārah al-kalām berbasis media sosial menggunakan aplikasi TikTok dengan mempersiapkan materi yang akan dijadikan bahan ajar sesuai dengan 4 capaian pembelajaran mata kuliah (CPMK) yang meliputi kemampuan percakapan dalam ranah perkenalan, di sekolah, di rumah, dan sosial, kemudian peneliti merekam video percakapan dalam aplikasi TikTok dengan memerankan orang $\mathrm{X}$ dan $\mathrm{Y}$ yang kemudian akan diduet oleh mahasiswa melalui aplikasi tersebut dengan cara hafalan. Hasil uji kelayakan didasarkan pada indikator kelayakan pada 3 komponen yakni, komponen kualitas materi pembelajaran, kualitas tampilan media pembelajaran, dan kualitas pengoperasian/penggunaan media pembelajaran. Dari uji kelayakan media pembelajaran oleh ahli media didapatkan persentase sebesar $85,7 \%$ yang dapat dikategorikan sebagai sangat layak, kemudian dari uji ahli materi didapatkan persentase sebesar 92,8\% dalam kategori sangat layak yang kemudian media pembelajaran tersebut diujicobakan secara luas (lapangan) kepada 42 mahasiswa dengan mendapatkan hasil persentase sebesar $82,12 \%$ dalam kategori sangat layak. Rerata dari hasil uji ahli dan uji coba tersebut di atas didapatkan hasil persentase sebesar $86,9 \%$ yang berati bahwa media pembelajaran mahärah al-kaläm berbasis media sosial menggunakan aplikasi TikTok ini sangat layak untuk digunakan.[]

\section{Daftar Rujukan}

Anderson, T., \& Dron, J. 2014. Teaching Crowds: Learning and Social Media. Athabasca: Athabasca University Press.

Argaheni, N. B. 2020. "Sistematik Review: Dampak Perkuliahan Daring Saat Pandemi COVID-19 Terhadap Mahasiswa Indonesia”, Placentum: Jurnal Ilmiah Kesehatan dan Aplikasinya, Vol. 8, No. 2.

Cahyono, A. S. 2016. Pengaruh Media Sosial Terhadap Perubahan Sosial Masyarakat di Indonesia. Jurnal Publiciana, Vol. 9, No. 1.

Damayanthi, A. 2020. "Efektivitas Pembelajaran Daring di Masa Pandemi Covid-19 Pada Perguruan Tinggi Keagamaan Katolik", Edutech, Vol. 19, No. 3.

Dilon, C. 2020. "Tiktok Influences on Teenagers and Young Adults Students: The Common Usages of the Application Tiktok", American Scientific Research Journal for Engineering, Technology, and Sciences (ASRJETS), Vol. 68, No. 1.

Eteläpelto, A., \& Lahti, J. 2008. "The Resources and Obstacles of Creative Collaboration in a LongTerm Learning Community”, Thinking Skills and Creativity, Vol. 3, No. 3.

G. Bowen, etc, W. n.d. Interactive Learning Online at Public Universities. Ithaka $S+R$. Retrieved January 17, 2021, from https://sr.ithaka.org/publications/interactive-learning-online-atpublic-universities-evidence-from-randomized-trials/

Galuh, I. G. A. A. K. 2017. Media Sosial dan Demokrasi: Transformasi Aktivitas Media Sosial ke Gerakan Nyata Bali Tolak Reklamasi. Yogyakarta: PolGov.

Grant, L. K., \& Courtoreille, M. 2007. “Comparison of Fixed-Item and Response-Sensitive Versions of an Online Tutorial”, Psychological Record, Vol. 57, No. 2.

Harmon, O. R., \& Lambrinos, J. 2006. "Online Format vs. Live Mode of Instruction: Do Human Capital Differences or Differences in Returns to Human Capital Explain the Differences in Outcomes?", Working papers (No. 2006-07), University of Connecticut. 
Hayes, C., Stott, K., Lamb, K. J., \& Hurst, G. A. 2020. "Making Every Second Count”: Utilizing TikTok and Systems Thinking to Facilitate Scientific Public Engagement and Contextualization of Chemistry at Home", Journal of Chemical Education, Vol. 97, No. 10.

Hutamy, E. T., Swartika, F., Alisyahbana, A. N. Q. A., Arisah, N., \& Hasan, M. 2021. "Persepsi Peserta Didik terhadap Pemanfaatan TikTok Sebagai Media Pembelajaran", Prosiding Penelitian Pendidikan Dan Pengabdian 2021, Vol. 1, No. 1.

Jung, H., \& Zhou, Q. 2019. "Learning and Sharing Creative Skills with Short Videos: A Case Study of User Behavior in TikTok and Bilibili", International Association of Societies of Design Research, Manchester.

Kaplan, A. M., \& Haenlein, M. 2010. "Users of the world, unite! The challenges and opportunities of Social Media", Business Horizons, Vol. 53, No. 1.

Koumi, J. 2015. "Learning Outcomes Afforded By Self-Assessed, Segmented Video-Print Combinations", Cogent Education, Vol. 2, No. 1.

Kuswoyo, K. 2017. "Konsep Dasar Pembelajaran Mahārah al-Kalām”, An-Nuha: Jurnal Kajian Islam, Pendidikan, Budaya dan Sosial, Vol. 4, No. 1.

Literat, I. 2021. "Teachers Act Like We're Robots: TikTok as a Window into Youth Experiences of Online Learning During COVID-19”, AERA Open, Vol. 7.

Mabruroh, A. F., Gunarhadi, P. D., \& Widyastono, D. H. 2020. "TikTok Application as Learning Media in Covid-19 Pandemic”, Journal of Critical Reviews, Vol. 7, No. 12.

Manca, S., \& Ranieri, M. 2016. "Facebook and the others. Potentials and obstacles of Social Media for teaching in higher education", Computers \& Education, Vol. 95, No. 1.

Media, K. C. n.d. "TikTok Punya 10 Juta Pengguna Aktif di Indonesia”, Retrieved January 18, 2021, from https://tekno.kompas.com

Muslimin. 2015. "Implementasi Pembelajaran Bermain Peran Untuk Meningkatkan Keterampilan Maharah Kalam Kelas VIII Madrasah Tsanawiyah Muhammadiyah Balassuka”, Thesis, Universitas Muhammadiyah Makassar.

Mustakim, M. 2020. "Efektivitas Pembelajaran Daring Menggunakan Media Online Selama Pandemi Covid-19 pada Mata Pelajaran Matematika”, Al-Asma: Journal of Islamic Education, Vol. 2, No. 1.

Nabilah, A., Lazuwardiyyah, F., Syaifuddin, S., \& Abdi, W. M. 2021. "Students' perception Toward the Use of Tiktok Video in Learning Writing Descriptive Text at MAN 1 Gresik", Journal of Research on English and Language Learning (J-REaLL), Vol. 2, No. 1.

an-Naqah, Mahmud Kamil. 1985. Ta’hm al-Lughah al-Arabiyah li al-Näthiqīn bi Lughāt Ukhrā: Ususuh-Madākhiluhu-Thuruq Tadrīsih. Mekkah: Jami'at Umm al-Qura.

Nastiti, L. W. 2016. "Bentuk Personal Branding Melalui Media Sosial (Studi Deskriptif Kualitatif Personal Branding Saptuari Sugiharto Melalui Akun Twitter Pribadi Saptuari)”, Thesis, UIN Sunan Kalijaga Yogyakarta.

Navarro, P., \& Shoemaker, J. 2000. "Performance and perceptions of distance learners in cyberspace”, American Journal of Distance Education, Vol. 14, No. 2.

Nurlaela, L. F. 2020. "Problematika Pembelajaran Bahasa Arab pada Keterampilan Berbicara di Era Revolusi Industri 4.0”, Prosiding Konferensi Nasional Bahasa Arab, Vol. 6, No. 6.

Hermida, A. Patricia Aguilera. 2020. “College students' Use and Acceptance of Emergency Online Learning Due to COVID-19”, International Journal of Educational Research Open, Vol. 1. 
Arabi : Journal of Arabic Studies

Polanyi, M. 2009. The Tacit Dimension. Chicago: University of Chicago Press.

Pratiwi, A. E., Ufairah, N. N., \& Sopiah, R. S. 2021. "Utilizing TikTok Application as Media For Learning English Pronunciation", International Conference on Education of Suryakancana (IConnects Proceedings).

Rovai, A. P., \& Jordan, H. 2004. "Blended Learning and Sense of Community: A Comparative Analysis with Traditional and Fully Online Graduate Courses", The International Review of Research in Open and Distributed Learning, Vol. 5, No. 2.

Saputra, D. S. 2017. "Interactive Learning Dalam Pembelajaran Speaking Di Kelas V Sekolah Dasar", Jurnal Cakrawala Pendas, Vol. 3, No. 1.

Subar, S. 2000. Al-Mustalah Khiyar al-Lughawy wa Simah Hadariyyah. n.p.: Kitab al-Ummah.

Suh, S. 2005. "Effect of Using Guided Questions and Collaborative Groups for Complex Problem Solving on Performance and Attitude in a Web-Enhanced Learning Environment", Thesis, Florida State University.

Utami, A. D. V. 2021. "Aplikasi Tiktok Menjadi Media Hiburan bagi Masyarakat Dan Memunculkan Dampak Ditengah Pandemi Covid-19”, Medialog: Jurnal Ilmu Komunikasi, Vol. 4, No. 1.

Wahlroos., \& Katariina, J. 2011. "Social Media as a Form of Organizational Knowledge Sharing: A Case Study on Employee Participation at Wärtsilä", Thesis, University of Helsinki.

Yu, J. X. 2019. "Research on TikTok APP Based on User-Centric Theory", Applied Science and Innovative Research, Vol. 3, No. 1.

Yulia, H. 2020. "Online Learning to Prevent the Spread of Pandemic Corona Virus in Indonesia", Eternal (English Teaching Journal), Vol. 11, No. 1. 